\title{
Feasibility of Student's Worksheet-Based Scientific Approach on Interaction of Living Things Material
}

\author{
Chairil Faif Pasani* \\ Department of Science Education \\ Universitas Lambung Mangkurat \\ Banjarmasin, Indonesia \\ chfaifp@ulm.ac.id
}

\author{
Ratna Yulinda \\ Department of Science Education \\ Universitas Lambung Mangkurat \\ Banjarmasin, Indonesia \\ ratna.yulinda@ulm.ac.id
}

\begin{abstract}
This study aims to produce a valid student worksheet-based on the scientific approach to develop the character of curiosity, responsibility, and environmental care of junior high school on the interaction of living things material. This research was a research and development study. Thiagarajan development model was used to include until the small group stage. This Research and Development (R\&D) involved expert validators and school practitioners to review student's worksheet format, language, and content. The results show that the student's worksheet has been developed is feasible to use in learning to develop student characters. Especially the character of curiosity, responsibility, and environmental care.
\end{abstract}

Keywords - feasibility, student's worksheet, scientific, student characters

\section{INTRODUCTION}

Science material in curriculum 2013 is leading to "integrative science" learning concept based on behaviorism theory, information gaining theory, and cognitive psychology theory (constructivism). In curriculum 2013, high school science learning materials expecting the achievement of learning goals and competence after individual learning. The objective gains when a teacher can create a suitable learning situation due to the students' and material characters in the shape of a learning model with supportive sources and tools[1][2]. The government has prepared textbooks as learning guidance contained with learning materials and students' worksheets in the implementation of curriculum 2013 through the education ministry. So the teachers can use student worksheets in the science textbook published by the Educational Ministry.

Permana said that the learning process must be able to increase the creativity of learners so that they more honed skills and produce output that is easy to the challenges of the $21^{\text {st }}$ century[3]. One of the very important things to prepare the learning is the right material to inform and it has to be suitable with the basic competency. It includes all supportive materials in the classroom learning process. There are many types of learning materials such as lesson books, modules, handouts, students' worksheets, etc. Paniwati and Permana said that learning materials that have been designed then need to be evaluated, one of them by giving the problem to the learners[4].

Students' worksheet is one of the media to help the learning process in to create effective interaction between students and educators, and it can also increase students activities in students achievements. Meanwhile, according to the Department of National Education students' worksheets are papers of tasks that the students have to do. It usually contains clues and steps to finish the tasks[5]. The advantage of using students' worksheets is to make teachers implementing learning easier and to make students learning independently, understanding and practicing their written tasks. Teachers are needed to make many kinds of media creatively[6]

The results of interviews with junior high school science teachers in Banjarmasin, it was found that the student's worksheet used was still obtained from certain publishers, so that the process skills of students were still difficult to observe, and had no obtained scientific-based using the wetland. Science learning provides opportunities for students to understand the natural surroundings with more experience because in science subjects students have the opportunity to study science through several disciplines. This research needs to be carried out because it still needs to create creative and innovative learning in education to improve student achievement, especially in science learning. The student worksheet was developed is based on the scientific approach in the wetland environment to builds student character namely curiosity, responsibility, and environmental care. It means that the content of the student worksheet is linked to wetland areas in South Kalimantan so local wisdom values of students can be realized through science learning.

Also one of a researcher in their research on character value in natural science education in Banjarmasin said that the student's character who changed from the criteria of "starting to indicate" to "starting to develop" [7]. The findings indicate that character education can be integrated into science learning. Other research suggests that character is something that is very important and needs to be developed because someone who has good and strong character individually and socially will have good morals, morals and, character[8]. Good character education must be formed and developed deliberately.

This research tries to develop students' worksheet-based scientific approach in wetland environments to develop the character of curiosity, responsibility, and environmental care. The students' worksheet contains the character and insights of wetlands as local wisdom in South Kalimantan.

Wetlands are included in the worksheet to increase student's knowledge so that they are familiar with the environment in the area where they live, especially South Kalimantan, which most of the territory is a wetland. Based on this description, it is necessary to develop a student worksheetbased scientific approach in a wetland environment to develop characters of curiosity, responsibility, and environmental care. 


\section{METHODS}

This research was a research development (R \& D). The model in this study used as a 4D model, according to Thiagarajan there are four steps in the development product namely the stage of define, design, develop, and disseminate. The first, define stage consist of preliminary analysis, student analysis, concept analysis, task analysis, and specification of learning objectives. Second, the design stage consists of test preparation, media selection, and initial design. The Student worksheet consists of the title, introduction, objectives, tools and material, and the procedures for a student. Third, the stage of development of the product and expert validation, smallscale trial, and limited class trials. Development testing was a product design trial activity on the actual subject target, as for the steps. In the development stage, namely 1) product validation by experts, in this case, three experts and two science teachers. And the last was the dissemination stage, which is an implementation of student worksheets on the target student seven grade in junior high school, but this stage can only be carried out in a limited manner because it was during the pandemic period.

The research was conducted on SMP Negeri 13 Banjarmasin. The research subject was a student of seven grade. The instrument used was student worksheet validation given to experts and practitioners. Student worksheet-based scientific approach can be determined by the suitability of validity score from validator with validity criteria. The validity value is given using the percentage calculation formula, as follows:

Percentage of validity $=\frac{T S e}{T S h} \times 100 \%$

The validity of the student worksheet-based scientific approach is determined by the suitability of the results with the specified validity criteria. Student worksheet validity criteria can be seen in Table I.

TABLE I. WORKSHEET VALIDITY CRITERIA [9]

\begin{tabular}{|c|l|l|}
\hline No. & Validity criteria $(\boldsymbol{\%})$ & Level \\
\hline 1 & $81,00-100,00$ & Very feasible \\
\hline 2 & $61,00-80,00$ & feasible \\
\hline 3 & $41,00-60,00$ & Enough \\
\hline 4 & $21,00-40,00$ & Less feasible \\
\hline 5 & $00,00-20,00$ & Not feasible \\
\hline
\end{tabular}

The practicality of expectations can be seen from the response of students to the worksheet that was developing. The response questionnaire used can describe student's responses to interest, pleasure, and easy learning components. This is given to students after following the learning process which includes objects of ease of use, benefits, and time efficiency. The validity and reliability of the questionnaire were analyzed in the same way as analyzing the validity of the student worksheet-based scientific approach. The questionnaire is arranged in ten statement items consisting of six positive statements and four negative statements. Students are asked to provide a checklist on the options that match their choice, namely strongly agree, agree, enough, disagree, and strongly disagree. Then this practicality is analyzed by giving a score on the responses of students using the following formula:

$$
\text { Response score }=\frac{\text { score }}{\text { maximum score }} \times 100 \%
$$

After obtaining the score calculation, then categorized according to the criteria below:

TABLE II. STUDENTS RESPONSE ASSESSMENT CRITERIA

\begin{tabular}{l|l|l|}
\hline No. & Percentage & Criteria \\
\hline 1 & $0-20$ & Strongly disagree \\
\hline 2 & $21-40$ & Disagree \\
\hline 3 & $41-60$ & Enough \\
\hline 4 & $61-80$ & Agree \\
\hline 5 & $81-100$ & Strongly agree \\
\hline
\end{tabular}

\section{RESULTS AND DISCUSSION}

\section{A. Development Product}

The product from this research and development is a student worksheet. This product was then tested for its feasibility to determine whether or not for use. The feasibility of student worksheets was seen from three things, namely validity, effectiveness, and practicality. The student worksheet being developed was a scientific approach based on wetlands to build a character of curiosity, responsibility, and environmental care. After the student worksheet design process that is produced includes the following criteria: (1) A4 paper size; (2) Consists of four activities that used in seven grade, namely interaction of living things with their environment; (3) Student worksheet prepared using the steps of scientific approach (observing, asking, trying, reasoning dan communicating); and (4)Student worksheet contain characters of curiosity, responsibility, and care for the environment in the part marked $(* *)$

\section{B. Student worksheet validation test results}

The development student worksheet validation was carried out to determine whether or not valid. Validation was carried out by 2 experts and 3 teacher practitioners at junior high schools in Banjarmasin. A student worksheet and validation sheet were submitted to the validator for construct validation, the results of validation obtained a percentage of $94,46 \%$ can be seen in Table III.

TABLE III. WORKSHEET VALIDATION RESULT

\begin{tabular}{|l|l|l|l|}
\hline No. & Assessment aspect & Percentage of validation & Criteria \\
\hline 1 & Worksheet formated & 91,25 & Very feasible \\
\hline 2 & Language & 100 & Very feasible \\
\hline 3 & Content & 92,14 & Very feasible \\
\hline & Overall validity & 94,46 & Very feasible \\
\hline
\end{tabular}

Calculation of student worksheet validation result assessment includes format aspect, language, and content which are included in very feasible criteria. The percentage is $94,46 \%$ shows that the student worksheet-based scientific approach developed has been declared valid without revision, but minor revisions are still carried out by the suggestion given by the validator for improving student worksheets. The suggestions given by the validator can be seen in Table IV below: 
TABLE IV. SUGGESTION FROM VALIDATORS ON THE STUDENT WORKSHEET-BASED SCIENTIFIC APPROACH

\begin{tabular}{|c|cl|} 
Validator & \multicolumn{2}{|l|}{ Suggestion } \\
\hline I & - & \\
\hline II & \begin{tabular}{lll} 
1. & The title of the student's worksheet too long \\
& 2. & Add a page that contains the features in the worksheet \\
& 3. & The image used will be better if you use a picture taken yourself \\
& 4. & Discourse from the newspapers is corrected so that there is no waste of words \\
\hline III & 1. & In the introduction, it is necessary to add environmental interaction. \\
\hline IV & - & \\
\hline V & 1. & It is necessary toad methods/instruction for using QR scans and consideration that \\
& junior high school students are not allowed to bring cellphones to school \\
& 2. & Can include how many hours of lesson and time in the report submission.
\end{tabular} \\
\hline
\end{tabular}

TABLE V. PRACTICAL STUDENTS WORKSHEET EXPECTATION

\begin{tabular}{|c|c|c|c|c|}
\hline \multicolumn{2}{|c|}{ Statement } & \multirow{2}{*}{ Score } & \multirow{2}{*}{ Percentage } & \multirow{2}{*}{ Criteria } \\
\hline 1 & Student worksheets used by teachers are very interesting to me & & & \\
\hline 2 & $\begin{array}{l}\text { In the slightest, I didn't understand learning when using student worksheets the interaction of living things } \\
\text { with their environment }\end{array}$ & 40 & 80 & Agree \\
\hline 3 & $\begin{array}{l}\text { With some of the activities on this worksheet, I feel I have gained more knowledge about environmental } \\
\text { activities }\end{array}$ & 42 & 84 & $\begin{array}{l}\text { Strongly } \\
\text { Agree }\end{array}$ \\
\hline 4 & The worksheet used made me tired of following science lesson & 40 & 80 & Agree \\
\hline 5 & $\begin{array}{l}\text { The worksheet used makes it easy for me to understand the material on the interaction of living things with } \\
\text { their environment }\end{array}$ & 40 & 80 & Agree \\
\hline 6 & $\begin{array}{l}\text { After learning to use worksheets I learned about the kinds of interactions between living things around my } \\
\text { environment }\end{array}$ & 47 & 94 & $\begin{array}{l}\text { Strongly } \\
\text { Agree }\end{array}$ \\
\hline 7 & This student worksheet is so abstract that it's hard to get me interested & 40 & 80 & Agree \\
\hline 8 & I feel that I can't distinguish between animals typical of South Kalimantan and those that are not & 34 & 68 & Agree \\
\hline 9 & When using this student worksheet, my curiosity about science material increases & 43 & 86 & $\begin{array}{l}\text { Strongly } \\
\text { Agree }\end{array}$ \\
\hline $\begin{array}{l}1 \\
0\end{array}$ & By using student worksheets I work well with my group and feel more responsible for my assignments & 44 & 88 & $\begin{array}{l}\text { Strongly } \\
\text { Agree }\end{array}$ \\
\hline \multicolumn{2}{|r|}{ Total Score } & \multicolumn{3}{|l|}{410} \\
\hline \multicolumn{2}{|c|}{ Percentage } & \multicolumn{3}{|l|}{82} \\
\hline \multicolumn{2}{|c|}{ Criteria } & \multicolumn{3}{|c|}{ Strongly agree } \\
\hline
\end{tabular}

The suggestions given by the validator are used as material to improve students' worksheet so that it becomes better.

\section{Practicality students worksheet test result}

The results of the students' worksheet practicality test can be seen in the table 5. Based on the results obtained by students' responses, the resulting worksheet obtained a percentage of $82 \%$ with strongly agree criteria.

The final product from this research was a student worksheet for seven grades of students in Junior High School in Banjarmasin. This product is based on wetland environments to develop characters of curiosity, responsibility, and environmental care. Preparation of learning tools refers to competencies in a science curriculum that uses a scientific approach. This Worksheet of four learning activities namely environment, What is in our environment, Interaction in the ecosystem form a pattern, and Human interaction patterns affect the ecosystem.

The results of the student worksheet assessment from the validator include format, language, and content. The results of the evaluation of the validity of the format are 91,25 , language 100, and content 92,14. All of which are very feasible criteria. The advantages of the worksheet that are compiled are in terms of the scientific approach used by the demands of the 2013 curriculum and contain character values in it, in this case, the character of curiosity, responsibility, and environmental care. Good teaching materials must pay attention to accuracy, suitability between the competencies that students must master in terms of content and relevance [9]. Furthermore, validity is a quality indicator before examining practicality and effectiveness [10]. The findings in this study are in line with the results that a scientific approach, when used in learning will have a positive impact on cognitive, affective, and psychomotor learning outcomes as well as classical completion[11].

The practicality of student worksheets is seen from the student response questionnaire in using the worksheet. This questionnaire consists of ten statements containing six positive and four negative statements. Student response questionnaires were used to find out the responses and opinions of students regarding worksheets that have been developed with a scale of respondents that students can choose consisting of five scales, namely strongly disagree, disagree, enough, agree, and strongly agree. Based on the results obtained by students' responses, the resulting worksheet obtained a percentage of $82 \%$ with strongly agree criteria. This means that the worksheet can be used to receive and obtain positive responses from students.

The practicality of the student worksheet was measured from the small group class trial. Small group trials were 
carried out by selecting ten students in seven grade. The simulation of the use of student worksheets was carried out on SMP Negeri 13 Banjarmasin in October 2020 online. The implementation of the process is carried out following the lesson plan that has been designed using the developed student worksheet.

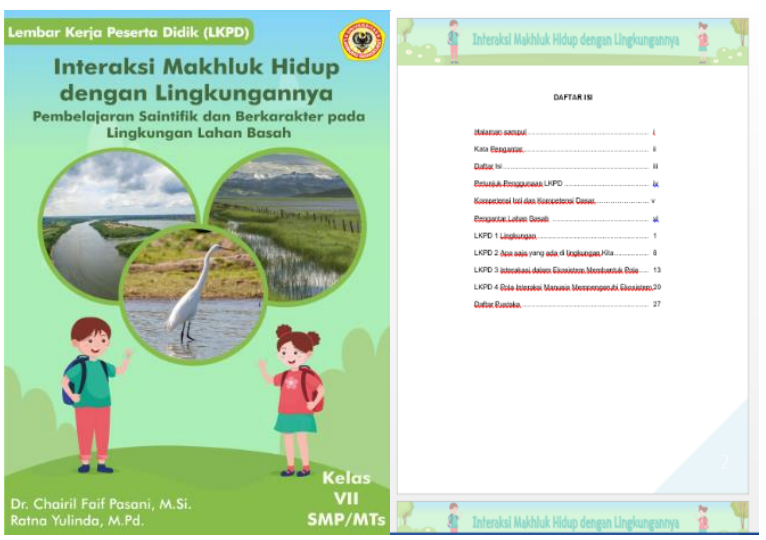

Fig. 1. Cover and table of content from students worksheet

The contents of the worksheet consist of scientific approach syntax which consists of five steps, namely observing, asking, trying, reasoning, and communicating. The observing activity prioritizes the meaning of the learning process. This method has advantages such as being able to present real objects, students are happy and challenged, and easy to implement. At this stage, a picture of Ikan Gabus (Channa striata) presented which is an animal that is often found by students in the South Kalimantan area. The activity of observing is very useful to fulfill the curiosity of students. Learning with a scientific approach influences student's critical thinking skills so it is good to use because it has a positive influence on learning [12]. Generally, "critical thinking is marked by the ability to think appropriately, systematically, and logically about a concept or belief as well as to take any action and solve problems based on a conceptual and argumentation analysis mechanism'[13]. Curiosity develops when students perform observational activities. They have curiosity because they look for themselves and ask and find out what the answer is. A curious person asks questions, reads information, and carries out an investigation[14].

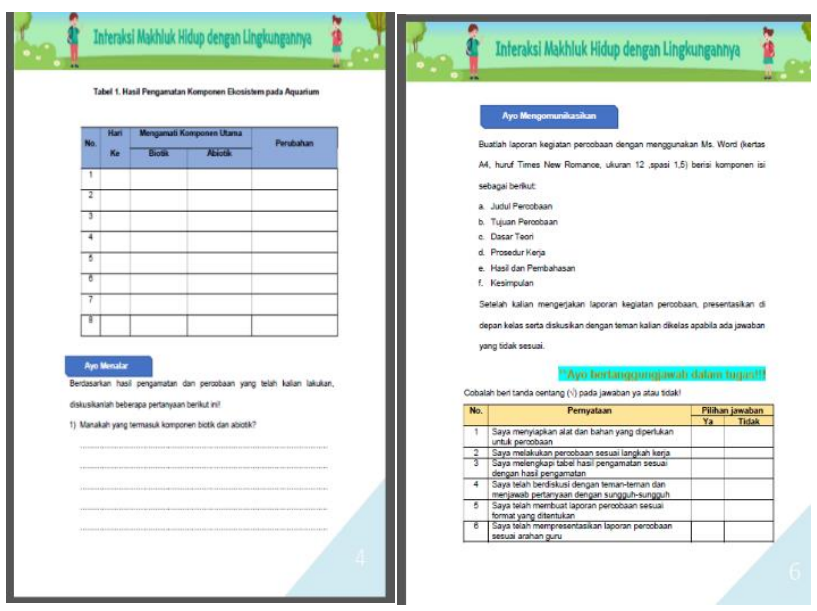

Fig. 3. Reasoning and communicating activities

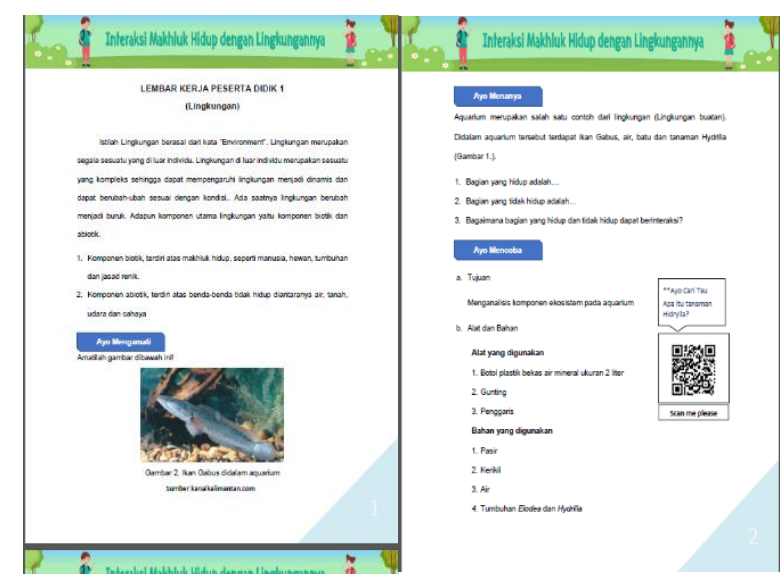

Fig. 2. The activity of observing, asking, and trying

The second step in scientific learning is to ask questions, it means either teacher or student can give a question, providing opportunities for students to ask or answer questions, the teacher fostering a familiar and pleasant learning atmosphere. Quality questions will produce quality answers. Students observe nature, the ask questions to make students independent in learning, especially cognitively[15][16]. Students' learning achievement can be measured by the way they memorize and report facts to understand the difficult concept with their knowledge[17]. Bolstad said "teachers and lecturers can use learners' responses to evaluate their readiness to learn and introduce new concepts by challenging the students' viewpoints [18].

Real learning outcomes will be obtained by students by trying or experimenting with the appropriate material or substance. The real learning activities for this are; [12] determining topics according to basic competencies and curriculum, [13]studying to use the tools and materials that are available and must be provided, [19] learning the relevant theoretical basis and the results of previous experiments, [20] conducting and observing experiments, [20] records the phenomena that occur, analyzes and presents data, [15] concluding on the results of the experiment, and [21] reporting and communicating the results of the experiment.

The learning process will be effective if there is direct interaction between teachers and students when viewed from the association theory. This interaction pattern occurs through the stimulus and response (S-R) process. According to Thorndike, the learning process of learners occurs slowly or gradually, not suddenly. There are two ways to do association, namely inductive and deductive logic. Inductive logic is a way of concluding general phenomena. Meanwhile, deductive logic is a way of concluding general phenomena to specific things. With this pattern students can process information with inductive logic from previous experiments, and by using deductive logic by comparing the results of the experiment with the concepts studied.

Teacher-centered learning will inhibit students' critical thinking[22] as resulting in students cannot learn independently, master concepts, and do not develop [23][24]. Teachers must be able to improve students thinking skills by training students during learning [25] in 
this case is reasoning the experiment result. Student needs the training to improve thinking and problem-solving skills. Cahyana said "the student scientific literacy can improve since there is critical thinking, wherein the critical thinking process involved an ability to interpret information and explore the solutions about the problem face up [26].

Reasoning activities allow students to use their understanding in real-world situations [27]. In the students' worksheet developed students are given reasoning activities for each activity so that they can practice their reasoning competencies on the experiment results to be compared with the scientific theory being studied. Science teachers have to know the importance of making a connection between science and a student's life. The learning of science should emphasize activities that enhance a student's experience to relate it to theory daily life[28].

The fifth learning step is to allow the student to communicate the results of a study to get responses from teachers and other students. Students are asked to communicate the results of their reasoning which can increase self-confidence and sincerity in learning. Communicating learning outcomes with and other students will also strengthen mastery of subject matter[19]. Learning that creates students confidence will make students feel comfortable and think positively during that learning. Besides, a variety of learning by presenting various regional potential in the worksheet. Learning with environmental nuance will provide facilities for interaction between student teachers and produce communication that is free from anxiety and stress[10,20]. Improving thinking skills is the mains goal in education [21]. By providing variety in learning will make students interested in learning without losing science conten[29].

\section{CONCLUSION}

This research has produced students' worksheets-based scientific approach on the interaction of living things material on wetlands to develop curiosity, responsibility, and environmental care characters with very feasible criteria and percentage $94,46 \%$. These results indicate that the development of a student worksheet-based scientific approach can be carried out in other materials even by providing a national character content, in this case, curiosity, responsibility, and environmental care. The result of this development indicates that student worksheets can be developed using a broader scientific approach as well as oth

\section{ACKNOWLEDGMENT}

Thank you to the Head of LPPM Universitas Lambung Mangkurat, Head of SMP Negeri 13 Banjarmasin for their willingness to work together and students of natural science education who helped a lot in this research activity.

\section{REFERENCES}

[1] R. Sulistyowati, "No Title,"www.eprints.uny.ac.id, 2015. [Online]. Available: http://eprints.uny.ac.id/ 21904/1/21Raya Sulistyowati.pdf.

[2] I. I. Widiyowati, "Hubungan kemampuan berpikir kritis dengan respon mahasiswa terhadap penggunaan model pembelajaran advance organizer pada materi larutan penyangga. Pancaran Pendidikan," www.jurnal.unej.ac.id, 2015. [Online]. Available: https://jurnal.unej.ac.id/index.php/pancaran/article/view/1331.
[3] F. H. Permana, "Pengembangan buku ajar biologi berbasis blended learning sebagai bekal hidup di abad 21 untuk mahasiswa S1 Kimia FMIPA UM," in Seminar Nasional Pendidikan Biologi 2015, yang diselenggarakan oleh Prodi Pendidikan Biologi FKIP Uni-versitas Muhammadiyah Malang, tema: "Peran Biologi dan Pendidikan Biologi dalam Menyiapkan Generasi Unggul dan Berdaya Saing Global," 2015, pp. 50-61.

[4] F. H. Pantiwati, Y., Wahyuni, S., \& Permana, "Instructional model of natural science in junior high schools, Batu - Malang," www.eric.ed.gov, $2017 . \quad$ [Online]. Available: https://eric.ed.gov/?id=EJ1139066.

[5] Depdiknas, Peraturan Pemerintah RI No.19 Tahun 2005 tentang Standar Nasional Pendidikan. Jakarta: Depdiknas, 2018.

[6] U. Dananjaya, Media pembelajaran aktif. Bandung: Nuansa Cendekia, 2013.

[7] R. Pasani, Chairil Faif, dan Yulinda, "Description of Student Character in Science Learning. 2020," . Int. J. Psychosoc. Rehabilitiation, vol. 24, no. 05, 2019

[8] I. P. Pasani, Chairil Faif, dan Januarta, "Implementasi model pembelajaran co-op co-op dalam pembelajaran matematika untuk mengembangkan karakter tanggung jawab peserta didik kelas viii smp," J. Pendidik. Mat., vol. 3, no. 1, pp. 39-48, 2015.

[9] S. Akbar, Instrumen Perangkat Pembelajaran. Bandung: PT. Remaja Rosdakarya, 2013

[10]T. Akker, J., bannan, B., Kelly, A. E. Nieveen, M. \& Plomp, "No Title," An Introd. to Educ. Des. Researc. Proceeedings Semin. Conduct. East China Norm. Univ. Shanghai (PR China), pp. 23-26, 2007.

[11]A. Machin, "Impelementasi pendekatan Saintifik, Penanaman karakter dan Konservasi Pada Pembelajaran Materi Pertumbuhan," $J$. Pendidik. IPA, vol. 3, no. 1, pp. 28-35, 2014.

[12] Y. pantiwati Yustyan, Septy, Nur widodo, "Peningkatan Kemampuan Berpikir Kritis dengan Pembelajaran berbasis Scientific Approach siswa Kelas X SMA Panjura Malang," J. Pendidik. Biol. Indones., vol. 1, no. 2, pp. 240-254, 2015.

[13]R. Cosgrove, "Improving teaching and learning of critical thinking across the curriculum at a large research university: An empirical study using qualitative methods. University of Cambridge," http://www.criticalthin

king.org/data/pages/45/d62c0654702626eac6a4504f8042a50a5240 8a877fe4f.pdf, 2012 . .

[14]M. Pitafi, A. I., Pur, R., \& Farooq, "Measurement of scientiific attitude of secondary school students in Pakistan. Academic Research International," www.savap.org.pk, 2012. [Online]. Available: http://www.savap.org.pk/ journals/ARInt./Vol.2(2)/2012(2.243).pdf.

[15]R. L. Arends, Classroom instruction and management. 1997.

[16]E. D. Zumbrunn, S., Tadlock, J., \& Roberts, "Encouraging selfregulated learning in the classroom: A review of the literature. Virginia: MERC (Metropolitan Educational Research Consortium)," www.scholarscompass. vcu.edu, 2011.

[17] S. Zubaidah, "Keterampilan abad ke-21: Keterampilan yang diajarkan melalui pembelajaran," Semin. Nas. Amin Adiansyah / JPBI (Jurnal Pendidik. Biol. Indones., vol. 4, no. 1, pp. 1-10, 2016.

[18]R. Bolstad, “Taking a 'future focus' in education-what does it mean? An NZCER working paper from the future-focussed issues in education (FFI) project," 2011

[19]N. A. S. Alghamdi, A. K. H., \& Hassan, "The effectiveness of the Mawhiba program for the development of critical thinking skills among gifted female students at the secondary levels. British Journal of Education Society \& Behavioural Science," https://doi.org/10.9734/BJESBS/2016/20367, 2016.

[20]R. Amin, A. M., \& Adiansyah, "Identifikasi gaya belajar \& respon mahasiswa untuk menentukan strategi pembelajaran pada perkuliahan fisiologi hewan," in Seminar Nasional V 2017 hayati Biologi, Sains, dan Pembelajarannya, 2016.

[21] M. Birjandi, P., \& Bagherkazemi, "The relationship between Iranian EFL teachers's critical thinking ability and their professional success," https://doi.org/10.5539/elt.v3n2p135, 2010.

[22] A. D. Amin, A. M., \& Corebima, Analisis persepsi dosen terhadap strategi pembelajaran reading, questioning, and answering (RQA) dan argument-driven inquiry (ADI) pada Program studi pendidikan 
biologi di kota Makassar. Malang: Prodi Pendidikan Biologi dan PSLK Universitas Muhammadiyah Malang, 2016

[23]M. Danial, "Pengaruh strategi PBL terhadap keterampilan metakognitif dan respon mahasiswa," www.doi.org, 2010. [Online]. Available: https://doi.org/10.26858/chemicann n,n,n,.v11i2.487

[24]A. M. Sardiman, Interaksi dan motivasi belajar mengajar. 2014.

[25]A. D. Corebima, "Pembelajaran biologi di Indonesia bukan untuk hidup," in Biology Education Conference, 2016, pp. 8-22.

[26]M. Cahyana, U., Kadir, A., \& Gherardini, "Relasi kemampuan berpikir kritis dalam kemampuan literasi sains pada siswa kelas IV sekolah dasar," www.doi.org, 2017. [Online]. Available: https://doi.org/10.17977/um009v26i12017p014.
[27]I. Humberstone, B., \& Stan, "Outdoor learning: Primary pupils' experiences and teachers' interaction in outdoor learning," www.doi.org, 2011. [Online]. Available: https://doi.org/10.1080/03004279.2010.487837.

[28]K. P. Revati, N., \& Meera, "An investigation of scientific attitude among secondary school students in Kottayam district of Kerala," www.doi.org, 2017.

[29] J. Sheldrake,S., Mujtaba, T., \& Reiss, M., "Science teaching and students' attitude and aspiration: The importance of converying the applications and relevance of science.," www.dx.doi.org, 2017. [Online]. Available: https://dx.doi.org/10.1016/j.ijer.2017.08.002. 